DOI: doi.org/10.21009/IJLECR.052.15

Received: 5 June 2019

Revised: 10 June 2019

Accepted: 14 August 2019

Published: 31 December 2019

\title{
ANALYSIS OF POLITENESS CONVERSATION AMONG TEACHER AND STUDENT IN WHAT'S APP APPLICATION
}

\author{
Tiara Noviarini $^{1, \mathrm{a})}$, Yulianto $^{2, \mathrm{~b})}$ \\ STMIK Mitra Karya Bekasi ${ }^{1)}$, STKIP Muhammadiyah Pringsewu Lampung ${ }^{2)}$ \\ tiaranoviarini@stmikmikar.ac.id ${ }^{\text {a) }}$,yulianto@ stkipmpringsewu-lpg.ac.id ${ }^{\text {b) }}$
}

\begin{abstract}
This study aims to find out the utterances in the conversation between teacher and students through the application message what's an app and it is to find out the utterances which include positive politeness and negative politeness. This research is a qualitative descriptive study. The method used observation and note-taking techniques. The sources of data in this study were a teacher and student conversations were taken through the messaging application What 's an app from September to December 2018. The findings obtained that students' politeness in conversation is not well placed. In addition, there were also found that students who seemed to dictate or schedule's teachers. Although there are also polite student utterances, non-polite speeches are more of a nature of not knowing norms or manners. There is much negative politeness than positive politeness.
\end{abstract}

Keywords: Politeness, Utterance, Messages Application, What's App

Humans are given different abilities with other beings, namely language skills. A language is a tool for communicating. One can convey all intentions and goals using language. Someone who will convey the intent and purpose must give their attention to the politeness of language that will be used. When someone used the language that is not polite in the communication process, it means that one is like as the uneducated people although they have high knowledge. Language is a system or rather a group of systems, namely a sound system, a grammar system, a meaning system, and variations in language use are often systematic (Thomas, Linda, and Shan Wareing, 2007: 17).

In the current situation, students sometimes used the language is not appropriate that they communicate with their teacher. When someone wants to communicate with other people whose age is above, you should use more polite language and polite sentence choices. Although the actual purpose conveyed is good, if it is not used the right sentences, people who are older will certainly feel less valued.

Language shows a personal reflection of someone. A person's character, temperament, or personality can be identified from the words spoken. Language use that is graceful, polite, systematic, orderly, clear, and straightforward reflects the personality of the speaker. The principle of politeness recommends that verbal communication is carried out politely, namely wise, easy to accept, humble, suitable, and sympathetic.

This discussion is certainly also related to a pragmatic theory which is the only one of linguistics level that examines language by taking into its users. Pragmatic experts define this term differently. Yule (1996: 3) for example, mentions four definitions of pragmatics, namely (1) a field that examines the meaning of the speaker; (2) fields that examines the meaning according to the 
context; (3) a field that exceeds the study of the meanings spoken, examines the meanings communicated, or communicates by the speaker; and (4) fields that examine the form of expression according to social distance which limits participants involved in certain conversations.

Definition of politeness is the same as etiquette. Politeness or etiquette is the procedure of custom that applies in a civilized society to maintain good relations between human beings. Politeness can be seen in various aspects of life in everyday life. (1) Politeness shows an attitude that contains the value of courtesy or etiquette in everyday relationships. (2) Politeness is very contextual, that is, it applies in a particular society, but it does not necessarily apply to other communities, places or situations. (3) modesty is always bipolar, which is having two-pole relationships, like people who are still young with older people. (4) modesty is reflected in how to speak (language), how to act (act), and how to dress (dress) (Sibarani, 2004: 171).

According to Fraser, politeness has many definitions: (1) politeness is property or part of speech; so it's not the utterance itself. (2) The hearer's opinion determines whether the politeness is in a speech. (3) Politeness is associated with the rights and obligations of the interaction participants (1978: 11). Among the rights of speakers in a conversation or interaction is the right to ask. However, this right is not without limits.

The researcher takes this discussion so that people can provide more attention to speech acts that are more polite in communicating process. Then, the language produced is also more polite. In addition, the result of the study is able to give a contribution to the people, the community can also distinguish between languages that are not polite, less polite, or more polite depending on who the other person is.

According to Brown and Levinson (1987: 92), politeness theory of language originates from the postulate of four basic strategies of speech, namely (1) speak up with bald on record, (2) speak up with small talk using positive politeness, (3) speak up with small talk using negative politeness, and (4) off record speaking. Brown and Levinson's politeness theory emerged with the second, third, and fourth strategies. The essence of Brown and Levinson's politeness theory is in conducting a speech act of request. A speaker must be able to maintain feelings (Wijana, 2004: 2) or respect the others, so as it is not face-threatening act.

According to Gunawan (2007: 215), the continuity of speech acts is not always parallel with politeness. Although language politeness is universal, its manifestations are vary as for its cultural community. It has to be remembered if the speaker thinks that their speech is polite, but it is not necessarily polite for the partner.

In this case, there are some researchers who have examined the politeness, Made Frida Yulia (2016) in her the research "Politeness Issues in Communication Over Text Messages". The research finding can be concluded that not all message senders have sociolinguistic competencies. Such as senders often ignore the concept of social distance and power relations, which should be considered when sending messages to their teachers.

The next researcher who has studied politeness is Olarak and Rica (2015), their title research is "Politeness Strategies used by L2 Turkish Speakers in Making Requests". The study found that adult speakers who learn Turkish tend to be polite and giving the attitude is not be forced than pragmatic clarity. The specific cultural context that requires knowledge of culture and social roles causes several problems for L2 speakers as illustrated by their sociolinguistic inappropriate choices about the second formal/informal differences in Turkey. This analysis reveals that cultural differences play an important role in the use of language and sociolinguistic competencies do not necessarily reflect linguistic competence.

The third researcher, Mike and Levy (2015), entitled "Politeness in Intercultural Email Communication: Australian and Korean Perspectives". The results of the study showed that the language used in the e-mail message was very polite but there were differences in politeness, both 
in expectations and usage, between Australian and Korean academics.

These two previous studies are certainly different from those studied now. In this case, researchers focus more on politeness in social media because it is the advancement of technology, of course, it can also affect someone. Technology should be able to help someone in positive action, rather than further exacerbate existing conditions.

\section{METHOD}

The research method is a qualitative method carried out by the following steps, namely data collection, data analysis, and presentation of the results of the analysis. The data collection was conducted from September 2018 to December 2018. There were many data found more than three months which contained elements of lack of courtesy rather than polite ones. The next step, data is obtained by using observation techniques through messages that enter through the WhatsApp. In addition, the note-taking technique is used as a continuation of the observation technique.

In data analysis, data consists of several stages, namely sorting data, identifying data, and answering problems. Sorting data is done to facilitate the analysis process considering the data source is quite a lot, it is possible that the same data appears repeatedly in the same context. Thus, sorting is done to avoid the same data being analyzed twice.

\section{RESULT AND DISCUSSION}

In the results of data analysis, it is done in narrative form. Presentation in narrative form is divided into two types, namely formal and informal methods (Sudaryanto, 1993: 145). The presentation of this analysis uses informal methods because the presentation of the analysis from this study used ordinary words.

\section{Analysis of Language Politeness Among Students and Teacher Through Conversations in Social Media What's App}

Data 1:

What's app date September 2, 2018

Student: Ass mam, I am chairman of the Management A. Are you here today?

Teacher: Waalaikumsalam, God willing, I entered. If I am not in class, I will contact first.

Student: Oh, thanks, mam?

The data (1), the writer sees that the utterance includes negative politeness because it is ideal if sending a message to the teacher should not be shortened. Especially if the sentence is poorly understood, as in the word Ass (Assalamualaikum). Then in the conversation at the end, students said oh, which is negative politeness because it shows dislike for the presence of a teacher.

\section{Data 2:}

What's app date September 6,2018

Student: Assalamualaikum mam, my thesis has not been checked yet? I want to take it on campus, but it doesn't work yet...hehehe

Teacher: Sorry, not yet.

Student: yes, already... trims

Based on these data, it seems that these students do not have politeness when he/she talked with the teacher. Students cannot distinguish the preparation of appropriate words for teacher and words are appropriate for their peers. This can be said as negative politeness because it seems to equate the partnership between teacher and peers. It can be seen from some words, such as 
abbreviations and slang: already, yes, hehehe (laugh), thanks (Thank you), these words are identical today for young people that is called slang. However, it is not appropriate to talk with the teacher, especially if it is discussed related to academic problems.

\section{Data 3:}

What's app date September 8,2018

Student: Still on campus mam? I was with $* * * *$ in Secretariat, but you were teaching ... but we were not going to miss.

Teacher: Now is in the secretariat mam? I am in there

Thee utterances in data (3), the sign $(*)$ is the name of the student that does not need to be mentioned. As a student, it is appropriate to wait for the teacher if there is a need. However, from the data above, it seems that the student does not need to be offended towards the teacher. This statement includes negative politeness because it is inappropriate for students to do it. Moreover, if the teacher is teaching, there is no need to be bothered, just they wait until the teacher has finished doing his assignment.

\section{Data 4:}

What's app date September 8, 2018

Student: Assalamualaikum mam, it's ***** I asked permission that I could not attend your class because I was still sick. Thanks, mom

In this data, the utterances were positive politeness because the student's statement only contains information that he or she cannot take studying. It is intended that the teacher gave permission because the student has notified him via text message on social media what's app. The sentence expressed is also quite polite when it expressed to the teacher.

\section{Data 5:}

What's app date September 8, 2018

Student: Afternoon mam, what time do you come tomorrow, Miss?

Teacher: 9 am, Translation

Student: until what time are you?

Teacher: a half eleven

Student: Oce, Miss

The data (5) above, it seems less appropriate to ask the teacher what time should it be because the student certainly can see the teacher's schedule. This includes negative politeness because ideally, the student seeks information on his own, not all told by the teacher unless there is information that the student must get the information from the teacher directly. Why do you have to ask the teacher's activity until the end, isn't it usually students already know the teacher for certain subjects must be completed.

\section{Data 6:}

What's app date September 9,2018

Student: which room will you, Miss.. ?? We have in there, Miss

The data 6 shown negative politeness. Ideally, before the teacher teaches, students should wait around the teaching and learning process took place, rather than they waited in the secretariat. 
In addition, it does not need to be asked to the teacher directly because students can see the teachers' room according to the teachers' schedule that has been listed. Even if there is a change in place, the teacher usually will notify the students that there is a change of room. So, the statements should not need to be sent via what's app to the teacher, just they wait on campus. The Study Program office is not for students who are waiting for lecturers before starting the teaching and learning process, but one of the Study Program's offices is for students who will deal with lecturers or other academic matters.

\section{Data 7:}

What's app date September 10, 2018

Student: Mam, is there Friday, I can**** meet you?

Teacher: It's around 3 o'clock.

The above statement includes positive politeness because it contains questions to the supervisor whether the supervisor can be found on Friday for thesis guidance. This is very reasonable to do and asked the supervisor because each teacher has his own schedule for thesis guidance. Therefore, the student must first ask for the schedule of consultation in accordance with the teacher's schedule.

\section{Data 8:}

What's app date September 10, 2018

Students : Assalamualaikum mam, it's ***** from *** semester 2 , Will we have lab mam?

Teacher: Yes, it's, as usual, the schedule

The word 'lab' in the statement means 'labor'. It is appropriate if there is a change in the practicum labour schedule, of course, the teacher will notify the previous day. If there is no notification, the practice will run according to the schedule as it should. From the above statement, it is implied that the student seemed to hope that there would not practice labor on that day for one reason or another. However, it turned out that the situation was not so. While there is no information given to students about the schedule changes from the teacher, it means that the schedule of practice labor is the usual schedule. This includes negative politeness because it seems that it does not need to be questioned by the teacher via the application message what's app.

\section{Data 9:}

What's app date October 4, 2018

Students: Ping, Assalamualaikum mam, are you there? Can **** go to your home in the afternoon? **** want to request your approval to be cover mam.

Teacher: I saw the revision in the first in the afternoon.

The utterance on data (9) arises because the student will meet his/her supervisor to request the thesis's approval. Ideally, when students completed the Comprehensive Examination, students must revise their thesis again in accordance with the criticisms and suggestions that have been given by examiners. After being revised, students must show the revised results to the examining teacher, whether they are correct or not. However, the reality has shown the different condition. This can be seen in the data above. The student immediately requests the thesis's approval to the supervisor and examiner. As an examiner, the examiner should be taken the revised results because this is not just an ordinary teacher, but a scientific work that must be made by students as one of the requirements 
to complete their study at the undergraduate level, especially in the English Literature Study Program. So, the utterances in this data include negative politeness because it is very inappropriate to be expressed to the teacher.

\section{Data 10:}

What's app date October 18, 2018

Student: Ping, Assalamualaikum mam, Are you at home? **** want to request the approval for my thesis miss, **** go to your home at 9 o'clock. Thanks, Miss

Teacher: I am busy at 9 o'clock. It's around 10 o'clock

Students: Yes mam, **** will be there at 10 o'clock.

As in the previous data, this is another one. In this data, the student seems to be the one who regulates or determines the supervisor schedule to meet them. It can be seen from the phrase "**** go to your home at 9 o'clock...". The * sign is deliberately omitted because it is the name of the student. It includes negative politeness. It means polite, but the method is not appropriate for the teacher. It can be seen that the student also determines his schedule to meet his supervisor. However, the teacher could not be met at this time, it was postponed at 10 o'clock. Supposedly if the student could be a little more polite, he could express by example a statement: ", What time will I meet you to correct my thesis Miss?" It is not polite if the student directly determines the time to meet. It is good if the teacher would reply to the student's message, sometimes there is a teacher that gets a message is not polite, the teacher does not want to reply to the message. And of course, the student will continue to look forward the reply of a message that actually doesn't return.

\section{CONCLUSION}

In this study, it found that negative politeness was more than positive politeness. This certainly can be used as a lesson for students why many students at this time are uncivilized in speaking with their teachers, especially if the speech is only through the messaging app WhatsApp. The increasingly sophisticated facilities to communicate, it can make it easier for someone to convey or ask something. However, it does not mean with impolite sentences. Especially if the speech is conveyed to an older person from the student, such as a teacher.

\section{REFERENCES}

Brown, P., dan Levinson, S.C. (1987). Universals in Language Usage: Politeness Phenomena. Questions and Politeness, Penyunting Esther N Goody. Cambridge: Cambridge University Press.

Fraser, B. (1978). Acquiring Social Competence in a Second Language, RELC Journal 9.1-21.

Gunarwan, A. (2017). Pragmatik: Teori dan Kajian Nusantara. Jakarta:Universitas Atma Jaya.

Helmita dan Idrus. (2015). Perbandingan Kesantunan Penyiar Radio Berbahasa Indonesia dan Jepang. Padang: Jurnal Kotoba Volume 2.

Nurjamily, Wa Ode. (2015). Kesantunan Berbahasa Indonesia dalam Lingkungan Keluarga. Kendari: Jurnal Humanika, No. 15, Volume 3 Bulan Desember,

Sibarani, R. (2004). Antropolinguistik. Medan: Poda.

Sudaryanto. (1993). Metode dan Aneka Teknik Analisis Bahasa: Pengantar Penelitian Wahana Kebudayaan Secara Linguistis. Yogyakarta: Duta Wacana.

Thomas, L., dan Wareing, S. (2007). Bahasa, Masyarakat, dan Kekuasaan. Yogyakarta: Pustaka Pelajar.

Wijana, I.D.P. (2006). Dasar-dasar Pragmatik. Yogyakarta.

Andi and Yule. (1996). G. Pragmatics. Oxford: Oxford University Press. 